\title{
Strategy to Enhance the Sugar Production Using Recyclable Inorganic Salt for Pre-Treatment of Oil Palm Empty Fruit Bunch (OPEFB)
}

\author{
Nursia Hassan, Nur Amirah Khairina Khairil Anwar, and Ani Idris* \\ Inorganic salts were used for the pretreatment of oil palm empty fruit \\ bunches (OPEFB) to enhance the delignification and saccharification yield \\ of OPEFB. The sequential pretreatment of OPEFB using sodium \\ phosphate dodecahydrate $\left(\mathrm{Na}_{3} \mathrm{PO}_{4} .12 \mathrm{H}_{2} \mathrm{O}\right)$ and zinc chloride $\left(\mathrm{ZnCl}_{2}\right)$ \\ proved to be an effective approach. OPEFB was delignified by $58.8 \%$, \\ producing a maximum total reducing sugar (TRS) yield of $0.97 \mathrm{~g} / \mathrm{g}$ under \\ optimum pretreatment conditions of $15 \% \quad \mathrm{Na}_{3} \mathrm{PO}_{4} .12 \mathrm{H}_{2} \mathrm{O}, 60$ min (30 \\ $\mathrm{min} /$ stage) pretreatment time, $10 \%$ solid to liquid ratio, and pretreatment \\ temperature of $121^{\circ} \mathrm{C}$. In addition, structural and morphological analysis \\ of the pretreated OPEFB using field emission scanning electron \\ microscope (FESEM), Fourier transform infrared (FTIR) spectroscopy, \\ and $\mathrm{X}$ - ray diffraction $(\mathrm{X}-\mathrm{RD})$ revealed major structural changes, such as \\ the generation of porous structure, which allows for better enzyme \\ accessibility. Moreover, recycle experiments showed encouraging \\ findings, as the spent pretreatment liquid with $\mathrm{pH}$ adjustment can be \\ recycled efficiently for at least 5 times without a substantial decrease in its \\ effectiveness.
}

Keywords: Palm oil empty fruit bunch; Pretreatment; Enzymatic hydrolysis; Inorganic salt

Contact information: Institute of Bioproduct Development (IBD), School of Chemical and Energy Engineering, Faculty of Engineering, Universiti Teknologi Malaysia, 81310 UTM Johor Bahru, Johor, Malaysia; *Corresponding author: aniidris@utm.my

\section{INTRODUCTION}

Sugars are important intermediate materials to produce various products of industrial applications such as food, biofuel, and bio-based chemicals. Sugar can be converted into wide variety of products using existing processing technologies including fermentation, hydrogenation, dehydrogenation, and oxidation. For example, bioethanol, 2,3-butanediol, lactic acid, and succinic acid can be produced via fermentation of hexose sugar using microorganisms (Hassan et al. 2017; Alam et al. 2019; Bukhari et al. 2019; Chen et al. 2019; Hazeena et al. 2019), while xylitol is obtained through hydrogenation of pentose sugar (Feher et al. 2018). The oxidation of 5-hydroxymethylfurfural (5-HMF), an intermediate product of the dehydration of glucose or fructose (Gao et al. 2015), can produce furandicarboxylic acid (FDCA).

Lignocellulosic agricultural residues such as corn stover, sugarcane bagasse, and oil palm biomass constitute the most abundant source of carbohydrates in nature. The use of these materials as a source of fermentable sugar is promising, as they do not compete with food sources. However, when processing lignocellulosic biomass, a harsher pretreatment is necessary in order to disrupt the recalcitrant structure of the lignocellulosic material, by breaking the lignin seal or decreasing crystallinity of cellulose to allow a better 
contact of enzymes and cellulose for subsequent conversion into monomeric sugars.

Lignocellulosic biomass is a potential feedstock for production of biobased chemicals as they are abundantly available, renewable, and cheap. The utilization of cellulosic biomass is driven by the ability to convert its high content of carbohydrate into sugars at low cost via thermo-chemical pre-treatment and hydrolysis (Lai and Idris 2016; Moodley and Kana 2017; Chen and Wan 2018; Lainez et al. 2018; Smits et al. 2019). To ensure satisfying margins and sustainability in biorefining industry when using lignocellulosic biomass, both pre-treatment and saccharification processes must be efficient to achieve minimal capital investment as well as the operating cost. These two unit operations contributed $20 \%$ of the overall capital and operating costs of biorefining (Cheng et al. 2019). Although there are many pretreatment methods developed, many of them are not financially viable. Their industrial application has been hampered by the high energy demand. Thus, effective and low cost pretreatment processes need to be developed and explored using these cheap and available lignocellulose biomass resources.

The annual output of an industrial agro-residue, oil palm empty fruit bunches (OPEFB), is approximately 2.9 million tons in Malaysia; it is a promising substrate to produce fermentable sugar (Latip et al. 2019). The three major components in OPEFB are cellulose (24 to 65\%), hemicellulose (21 to 34\%), and lignin (14 to 31\%) (Hassan et al. 2017; Palamae et al. 2017; Akhtar et al. 2019). The high carbohydrate content is one of the major reasons for the use of OPEFB to produce monosaccharides. However, OPEFB biomass requires pretreatment steps to ensure that the recalcitrant structure of biomass is disrupted before it can be turned into sugars through hydrolysis (Shamsudin et al. 2012; Hassan and Idris 2016; Zulkiple et al. 2016). Pretreatment generally increases the available surface area for enzymatic attack. The removal of lignin and hemicellulose increases the pore size and accessibility of the substrate to enzymes and catalyst. Hence, cellulose can be penetrated easily by the catalysts, and the conversion process of biomass improved. To obtain high glucose yield by enzymatic hydrolysis, it is crucial to have an effective pretreatment process to fulfil the biorefinery of OPEFB.

There are various pretreatment methods including physical (e.g., mechanical and extrusion), chemical (e.g., alkali, acid, ionic liquid), physicochemical (e.g., steam explosion, ammonia fiber explosion, microwave), and biological processes (Abdul et al. 2016; Medina et al. 2016; da Silva Machado and Ferraz 2017; Sorn et al. 2019). Many studies have yielded significant progress by achieving sustainable pretreatment solutions for lignocellulosic biomass on a large scale. Effective and viable pretreatment is more than just the disruption of substrate matrix to increase the porosity and surface area of the biomass; it must be performed in moderate energy demand and minimal production cost.

For OPEFB, alkaline pre-treatment is preferred, as this pre-treatment method increases porosity and internal surface area of biomass by promoting structural swelling, dissolving the lignin, and decreasing the degree of polymerization and crystallinity (Nomanbhay et al. 2013; Sudiyani et al. 2013; Hassan et al. 2017). It is performed at low $(0.5$ to $4 \mathrm{wt} \%$ ) or high ( 6 to $20 \mathrm{wt} \%) \mathrm{NaOH}$ concentrations. At higher $\mathrm{NaOH}$ concentration, the process occurs at atmospheric pressure and low temperature, and cellulose dissolution ensues without significant delignification. At low $\mathrm{NaOH}$ concentration, pre-treatment requires higher temperature $\left(135\right.$ to $\left.180{ }^{\circ} \mathrm{C}\right)$, pressure $(0.1$ to $0.6 \mathrm{MPa})$, and reaction time ( 2 to 12 hours) to effectively remove lignin and hemicellulose (Akhtar et al. 2014: Palamae et al. 2017; Thamsee et al. 2019). However, the use of $\mathrm{NaOH}$ has several disadvantages, such as it can lead to a highly violent reaction and high energy demand, as it requires a high reaction temperature and long reaction time. 
Inorganic salt pretreatment has received considerable attention as a novel and effective chemical pretreatment method because of its cost-effectiveness and recyclable nature (López-Linares et al. 2013; Qing et al. 2016; Romero et al. 2018). Alkali salts and metal type salt are types of inorganic salt that have been used in pretreatment of lignocellulose biomass (Kang et al. 2013; Sewsynker-Sukai and Kana 2017; SewsynkerSukai and Kana 2018). The use of alkali salts such as $\mathrm{Na}_{3} \mathrm{PO}_{4} \cdot 12 \mathrm{H}_{2} \mathrm{O}, \mathrm{Na}_{2} \mathrm{CO}_{3}$, and $\mathrm{Na}_{2} \mathrm{~S}$ in pretreatment resulted in dissolution of lignin and hemicellulose, de-esterification of intermolecular ester bonds, and disruption of crystalline structure of cellulose (SewsynkerSukai and Kana 2018). Metal salts including $\mathrm{ZnCl}_{2}, \mathrm{FeSO}_{4}$, and $\mathrm{FeCl}_{3}$ cleave glycosidic linkages within lignocellulosic structures by forming metal cations that act as Lewis acids in the pretreatment solution (Liu et al. 2009; Kang et al. 2013; Amarasekara and Deng 2019; Wei et al. 2019). Some combinations of alkali salts and metal salts are efficient for lignocellulosic pretreatment (Sewsynker-Sukai and Kana 2018).

To date, there has been no report on the use of inorganic salts in the pretreatment of palm oil biomass to produce sugars. Some research has indicated that inorganic salts pretreatment are effective in producing sugars from corncobs and bamboo shoot shell (Qing et al. 2016; Sewsynker-Sukai and Kana 2017, 2018). Due the complexity of different biomass structure and composition, the results of the same pretreatment method when applied to different types of biomass tend to give different results. Moreover, the optimum operating conditions for inorganic salt pretreatment are very dependent on the type of biomass. Based on this complicating factor, this study examined a strategy to maximize the delignification effect to enhance the enzymatic saccharification of OPEFB for sugar production using inorganic salt. The sequential pretreatment of OPEFB using sodium phosphate dodecahydrate $\left(\mathrm{Na}_{3} \mathrm{PO}_{4} .12 \mathrm{H}_{2} \mathrm{O}\right)$ and zinc chloride $\left(\mathrm{ZnCl}_{2}\right)$ was used for the first time to pretreat OPEFB. The impacts of some critical operating parameters such as pretreatment time, solid to liquid ratio, and $\mathrm{Na}_{3} \mathrm{PO}_{4} .12 \mathrm{H}_{2} \mathrm{O}$ concentration were systematically evaluated. The structural and morphological changes of the pretreated OPEFB were also determined by $\mathrm{X}$ - ray diffraction (XRD), field emission scanning electron microscope (FESEM), and Fourier transform infrared (FTIR) spectroscopy. In order to make the pretreatment process more competitive, the black spent liquor that was produced from the pretreatment was tested for its recyclability so as to minimize the wastewater accumulation and to reduce the production cost of sugar.

\section{EXPERIMENTAL}

\section{Preparation of OPEFB Feedstock and Chemicals}

The ground OPEFB was provided by Biotrade Noh Resources, Bandar Penawar, Johor, Malaysia. These ground materials have lengths of 3 to $5 \mathrm{~mm}$. The received OPEFB fibres were washed to remove dirt and soil and then dried to a constant weight in an oven at $60{ }^{\circ} \mathrm{C}$ for $48 \mathrm{~h}$. The dried OPEFB fibers were stored in a sealed plastic bag at room temperature until further use.

All chemical reagents and enzymes were of analytical grade and used as received without further purification. Tri-sodium phosphate 12-hydrate $\left(\mathrm{Na}_{3} \mathrm{PO}_{4} .12 \mathrm{H}_{2} \mathrm{O}\right)$ and zinc chloride $\left(\mathrm{ZnCl}_{2}\right)$ used in the pretreatment of OPEFB biomass were obtained from Sigma Aldrich (St. Louis, MO, USA) and Merck (Darmstadt, Germany). Other chemicals such as acetic acid $\left(\mathrm{CH}_{3} \mathrm{COOH}\right)$, sodium chlorite $\left(\mathrm{NaClO}_{2}\right)$, sodium hydroxide $(\mathrm{NaOH})$, and sulfuric acid $\left(\mathrm{H}_{2} \mathrm{SO}_{4}\right)$ were all purchased from Merck (Darmstadt, Germany) and used in 
the composition characterization of OPEFB. Citric acid $\left(\mathrm{C}_{6} \mathrm{H}_{8} \mathrm{O}_{7} \cdot \mathrm{H}_{2} \mathrm{O}\right)$ and trisodium citrate dihydrate $\left(\mathrm{C}_{6} \mathrm{H}_{5} \mathrm{O}_{7} \mathrm{Na}_{3} .2 \mathrm{H}_{2} \mathrm{O}\right)$ were mixed so as to prepare the $50 \mathrm{mM}$ sodium citrate buffer. The amount of total reducing sugar (TRS) present was determined using DNS reagent, which was prepared by mixing $\mathrm{NaOH}, 3$,5-dinitrosalicylic acid $\left(\mathrm{C}_{7} \mathrm{H}_{4} \mathrm{~N}_{2} \mathrm{O}_{7}\right)$, and sodium potassium tartrate tetrahydrate $\left(\mathrm{KNaC}_{4} \mathrm{H}_{4} \mathrm{O}_{6} .4 \mathrm{H}_{2} \mathrm{O}\right)$ in the required proportions. Cellic CTec 2 enzyme from Novozymes (80 FPU/mL) was employed in the enzymatic hydrolysis.

\section{Inorganic Salt Pretreatment Protocol}

The experimental protocol for the sequential inorganic salt pretreatment consisted of two stages, in which $\mathrm{Na}_{3} \mathrm{PO}_{4} .12 \mathrm{H}_{2} \mathrm{O}$ and $\mathrm{ZnCl}_{2}$ were used for the first and second pretreatment stages, respectively. The procedures are as follows:

i) $10.0 \mathrm{~g}$ of OPEFB was added into a $250 \mathrm{~mL}$ Scott bottle containing $100 \mathrm{~mL}$ of $\mathrm{Na}_{3} \mathrm{PO}_{4} .12 \mathrm{H}_{2} \mathrm{O}$ solution. The mixture was then stirred until the solid fraction was immersed into the liquid completely before heating to $121{ }^{\circ} \mathrm{C}$ for $30 \mathrm{~min}$ using autoclaving (ALP CL-32LDP, Japan). After pretreatment, the reaction was quenched by cooling it using ice-water mixture. The solid fraction was then filtered using cotton cloth and washed with distilled water several times.

ii) In a second step, the solid residue of $\mathrm{Na}_{3} \mathrm{PO}_{4} .12 \mathrm{H}_{2} \mathrm{O}$ pretreated OPEFB, which was obtained from first stage of pretreatment, was then mixed with $100 \mathrm{~mL}$ of $5 \%$ $\mathrm{ZnCl}_{2}$ solution and heated using autoclave at $121{ }^{\circ} \mathrm{C}$ for $30 \mathrm{~min}$. After the second stage of pretreatment, the solid fraction was collected and washed until a neutral $\mathrm{pH}$ was achieved. The sequential inorganic salt pretreated OPEFB biomass was dried at $85{ }^{\circ} \mathrm{C}$ overnight and kept for subsequent experiments.

Control experiments to analyse the effect of single pretreatment that utilised only water, only $15 \%$ (w/v) $\mathrm{Na}_{3} \mathrm{PO}_{4} .12 \mathrm{H}_{2} \mathrm{O}$, and only $5 \%$ (w/v) $\mathrm{ZnCl}_{2}$ were performed. The pretreatment efficiency was measured by the compositional changes and the reducing sugar yields evaluated after enzymatic hydrolysis. In addition, the influences of operating parameters, such alkali salt $\mathrm{Na}_{3} \mathrm{PO}_{4} .12 \mathrm{H}_{2} \mathrm{O}$ concentration $(5.0 \%, 10.0 \%, 15.0 \%$, and $20.0 \%$ $\mathrm{w} / \mathrm{v})$, reaction time $(15,30$, and 60 min per stage), and biomass loading $(5,10$, and $15 \%$ of solid to liquid ratio) were also evaluated.

\section{Compositional Analysis of OPEFB}

Holocelluloses content were evaluated base on the procedure used by Teramoto et al. (2009). TAPPI test method (2009) was used to determine the $\alpha$-cellulose content and the difference between holocellulose and cellulose is a measure of the hemicellulose amount in OPEFB. The acid insoluble lignin amount (Klason's lignin) was quantified using the NREL standard protocol (Sluiter et al. 2006). All verification procedures were performed in duplicates. In order to ensure that attained results were reproducible, the standard error was set to no more than 5\%, revealing the reliability of the fiber analysis (Van Soest et al. 1991; Lai and Idris 2013)

\section{FT-IR Spectroscopy Analysis}

The changes in functional groups of various pretreated and native samples of OPEFB were analysed using FT-IR spectra between 4000 to $450 \mathrm{~cm}^{-1}$ wave number using a Perkin Elmer spectrometer (Waltham, MA, USA). Discs were prepared by mixing the

Hassan et al. (2020). "Sugar from empty fruit bunch," BioResources 15(3), 4912-4931. 
dry OPEFB samples with $200 \mathrm{mg} \mathrm{KBr}$ in a granite mortar and pressed at $10 \mathrm{MPa}$ for approximately $3 \mathrm{~min}$. The readings were recorded in transmission mode.

\section{XRD Analysis}

Raw and pretreated OPEFB samples were analysed for crystallinity indices using a Rigaku X-ray Diffractometer (Smartlab, Rigaku, Tokyo, Japan). The cellulose crystallinity index, CrI, was calculated using Eq. 1 (Segal et al. 1959),

$$
\operatorname{CrI},(\%)=\frac{I_{\text {crystalliritam }}-I_{\text {amorphous }}}{I_{\text {crysallitiv }}} \times 100 \%
$$

where, $I_{\text {crystalline }}$ is diffracted intensity at 20 to $22.5^{\circ}$ and $I_{\text {amorphous }}$ is diffracted intensity of amorphous portion at 20 to $18.0^{\circ}$.

\section{Morphology Analyses}

Field emission scanning electron microscopy (FESEM, HITACHI, SU8020, Tokyo, Japan) was operated at $15 \mathrm{kV}$ to analyse the surface morphology of untreated raw and pretreated OPEFB samples. The samples were sputter coated with a thin layer of gold using automated sputter coater system (Q150RS, Quorum Technologies, East Sussex, UK) prior to imaging at magnification range of 200 to $20 \mu \mathrm{m}$.

\section{Enzymatic Saccharification Study}

The efficiency of pretreatment methods were measured by the digestibility of treated OPEFB in enzymatic hydrolysis. The saccharification of treated samples and native OPEFB were conducted in conical flasks containing hydrolysis mixture, which consisted

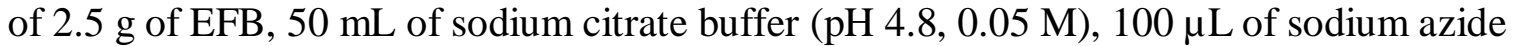
$(2 \% \mathrm{w} / \mathrm{v})$ ), and Cellic CTec2 enzymes (20 FPU/g OPEFB). The hydrolysis mixture was incubated at $50{ }^{\circ} \mathrm{C}$ and $150 \mathrm{rpm}$. Enzymatic hydrolysates were collected at 1, 4, 8, 24, 48 and $72 \mathrm{~h}$ and subsequently analysed to quantify the amount of total reducing sugar (TRS) release using the 3,5-dinitrosalicylic acid (DNS) method.

\section{Reducing Sugar Content Analysis}

The TRS yields produced during the enzymatic hydrolysis of the OPEFB fibers were quantified using DNS assay. The DNS reagent was prepared according to Ghose (1987), where sodium potassium tartrate tetrahydrate, 3, 5-dinitrosalicylic acid, and $\mathrm{NaOH}$ solution were mixed together. A total of $2 \mathrm{~mL}$ of the prepared DNS reagent was mixed with one $\mathrm{mL}$ of enzymatic hydrolysate and subsequently heated in a water bath for 5 min at $100{ }^{\circ} \mathrm{C}$. After the mixed solution was cooled to room temperature, the absorbance was measured using UV-Vis spectrophotometer at a wavelength of $540 \mathrm{~nm}$. The yield of TRS are calculated using Eq. 2.

$$
\text { TRS yield }\left(\frac{g}{g}\right)=\frac{\text { Sugar recovered }\left(\frac{g}{L}\right) \times \text { Volume of solvent used }(L)}{\text { Mass of OPEFB used }(g)}
$$

\section{Recycling of Spent Pretreatment Liquid}

The effects of spent pretreatment liquid recycling on enzymatic hydrolysis and TRS yield were evaluated by recycling experiments. The spent liquid that was produced during the pretreatment was used again to treat the OPEFB. The spent $\mathrm{Na}_{3} \mathrm{PO}_{4} .12 \mathrm{H}_{2} \mathrm{O}$ and $\mathrm{ZnCl}_{2}$ was collected after filtration and used to pretreat subsequent batches of OPEFB sample under optimized conditions. These recycling experiments were repeated until a significant 
decrease in TRS yield was observed. An identical experiment was carried out with adjustment of alkaline $\mathrm{Na}_{3} \mathrm{PO}_{4} \cdot 12 \mathrm{H}_{2} \mathrm{O}$ spent liquid $\mathrm{pH}$ to initial $\mathrm{pH}$ by $5 \mathrm{M} \mathrm{NaOH}$ for comparison. The pretreated solid residue was filtered, washed, collected, and analysed for TRS yield.

\section{Statistical Analysis}

All hydrolysis experiments were conducted in triplicates, and errors were within \pm $5 \%$. The data are presented in statistical average values. The significant differences among the experimental data were statistically analysed using analysis of variance (ANOVA) with Tukey's test (significance level of $\mathrm{p}<0.05$ ). The recommended conditions for effective pretreatment of OPEFB using sequential inorganic salt pretreatment was determined using statistical analysis.

\section{RESULTS AND DISCUSSION}

\section{Compositional Analysis of OPEFB}

High delignification rate, increase of cellulose content, and removal of hemicellulose were indicators used to evaluate the effectiveness of the various pretreatment processes. Table 1 reveals the composition of raw OPEFB, which contained $21.1 \%$ lignin, $18.9 \%$ hemicellulose, and $51.1 \%$ cellulose. The single stage inorganic salt pretreatment using alkali salt $\left(\mathrm{Na}_{3} \mathrm{PO}_{4} .12 \mathrm{H}_{2} \mathrm{O}\right)$ and metal salt $\left(\mathrm{ZnCl}_{2}\right)$ resulted in a lignin removal of $26 \%$ and $2.5 \%$, respectively. Alkali salt $\left(\mathrm{Na}_{3} \mathrm{PO}_{4} .12 \mathrm{H}_{2} \mathrm{O}\right)$ pretreatment was more efficient in removing lignin compared with metal salt $\left(\mathrm{ZnCl}_{2}\right)$. The effectiveness of alkali salts $\mathrm{Na}_{3} \mathrm{PO}_{4} .12 \mathrm{H}_{2} \mathrm{O}$ was attributed to the strong nucleophilic species such as $\mathrm{PO}_{4}{ }^{3-}$ and $\mathrm{HPO}_{4}{ }^{2}$, which cleave the phenolic $\beta$-aryl ether bonds present in lignin wall matrix, subsequently altering the lignin structure. Furthermore, alkali salt has the ability to cleave the ester and glyosidic bonds of cell wall matrix, consequently modifying lignin structure. Conversely, weak acid such as metal salt of $\mathrm{ZnCl}_{2}$ was not able to do the same.

Table 1. Effect of Different Pretreatment Methods on the Chemical Compositions of OPEFB

\begin{tabular}{|c|c|c|c|c|c|c|}
\hline \multirow[b]{2}{*}{ Sample } & \multirow{2}{*}{$\begin{array}{l}\text { Solid } \\
\text { recovery } \\
(\%)\end{array}$} & \multicolumn{3}{|c|}{ Chemical composition of OPEFB } & \multirow{2}{*}{$\begin{array}{l}\text { Hemicellulose } \\
\text { removal (\%) }\end{array}$} & \multirow{2}{*}{$\begin{array}{l}\text { Lignin } \\
\text { removal } \\
(\%)\end{array}$} \\
\hline & & Cellulose & Hemicellulose & Lignin & & \\
\hline $\begin{array}{c}\text { Raw OPEFB- } \\
\text { Untreated }\end{array}$ & 100.0 & $51.1 \pm 1.8$ & $18.9 \pm 0.8$ & $21.1 \pm 0.3$ & - & - \\
\hline $\begin{array}{c}\text { Water } \\
\text { pretreatment }\end{array}$ & 93.0 & $57.8 \pm 1.2$ & $17.3 \pm 0.4$ & $20.8 \pm 0.7$ & 8.5 & 1.4 \\
\hline $\begin{array}{c}\mathrm{Na}_{3} \mathrm{PO}_{4} .12 \mathrm{H}_{2} \mathrm{O} \\
\text { pretreatment }\end{array}$ & 76.0 & $63.9 \pm 0.3$ & $17.0 \pm 1.1$ & $15.6 \pm 0.4$ & 10.1 & 26.1 \\
\hline $\begin{array}{c}\mathrm{ZnCl}_{2} \\
\text { pretreatment }\end{array}$ & 91.0 & $59.3 \pm 0.8$ & $13.5 \pm 0.3$ & $20.6 \pm 0.1$ & 28.6 & 2.4 \\
\hline $\begin{array}{c}\text { Sequential } \\
\text { pretreatment of } \\
\mathrm{Na}_{3} \mathrm{PO}_{4} 12 \mathrm{H}_{2} \mathrm{O}- \\
\mathrm{ZnCl}_{2}\end{array}$ & 72.0 & $80.3 \pm 1.0$ & $6.1 \pm 0.8$ & $8.7 \pm 0.4$ & 67.7 & 58.8 \\
\hline
\end{tabular}

Hassan et al. (2020). "Sugar from empty fruit bunch," BioResources 15(3), 4912-4931. 
A single pretreatment of $\mathrm{Na}_{3} \mathrm{PO}_{4} \cdot 12 \mathrm{H}_{2} \mathrm{O}$ and $\mathrm{ZnCl}_{2}$ resulted in the hemicellulose removal of $9.8 \%$ and $28.8 \%$, respectively. Although a weak acid such as metal salt of $\mathrm{ZnCl}_{2}$ was not able to cleave phenolic $\beta$-aryl ether bonds present in lignin wall matrix, it has a unique ability to cleave the ether bonds between xylan polymers, resulting in higher removal of hemicellulose.

When these $\mathrm{Na}_{3} \mathrm{PO}_{4} .12 \mathrm{H}_{2} \mathrm{O}-\mathrm{ZnCl}_{2}$ pre-treatments were performed sequentially, the removal of lignin was very high $(58.8 \%)$. These results indicated that the combination of these two salts (alkali and metal) is the best strategy because highest cellulose content, hemicellulose removal, and delignification were achieved simultaneously. The synergistic effect of $\mathrm{Na}_{3} \mathrm{PO}_{4} .12 \mathrm{H}_{2} \mathrm{O}-\mathrm{ZnCl}_{2}$ is undeniable, as the cellulose content increased to $80.3 \%$, while hemicellulose and lignin were reduced to $6.12 \%$ and $8.7 \%$, respectively. The ability of $\mathrm{Na}_{3} \mathrm{PO}_{4} .12 \mathrm{H}_{2} \mathrm{O}$ to cleave phenolic $\beta$-aryl ether bonds in the lignin wall matrix and $\mathrm{ZnCl}_{2}$ unique function to cleave ether bonds between xylan polymers have contributed to the triple effect of significant increase in cellulose content, high hemicellulose removal, and delignification rate.

Previous studies on metal salt-based lignocellulosic pretreatment reported similar observations when using corn stover and Miscanthus straw as substrates (Liu et al. 2009; Kang et al. 2013). However, the use of $\mathrm{ZnCl}_{2}$ effectively removed the hemicellulose compared with $\mathrm{Na}_{3} \mathrm{PO}_{4} \cdot 12 \mathrm{H}_{2} \mathrm{O}$. There was less damage in the hemicellulose structure when using only alkali salt during the pretreatment (Qing et al. 2016; Sewsynkar Sukai and Kana 2018). A similar observation was reported by Sewsynkar Sukai and Geuguim Kana (2018), where $\mathrm{Na}_{3} \mathrm{PO}_{4} .12 \mathrm{H}_{2} \mathrm{O}$ and $\mathrm{ZnCl}_{2}$ were used to enhance the delignification of corncobs. In their study, delignification of $63.6 \%$, a $75.3 \%$ increase in cellulose content, and $27.5 \%$ removal of hemicellulose was achieved under optimal conditions.

\section{Functional Group Analysis of OPEFB}

The variation of functional groups of raw and different pretreated OPEFB were determined using FTIR spectroscopy. Structural changes of biomass sample before and after pretreatment were characterized through the changes of the transmittance band in the spectrum.

Figure 1 illustrates the curves representing the raw and various pretreated OPEFB samples. The spectral patterns of the curves were similar, demonstrating that the main chemical functional groups of OPEFB were essentially alike after being subjected to the various pretreatments. No significant differences were observed for raw and waterpretreated OPEFB spectra. However, the intensities of some specific transmittance peaks were reduced for OPEFB samples subjected to inorganic salt pretreatment, signifying that there were some changes in chemical functional group amounts.

Differences in spectra occurred in the wavelength region of 1000 to $2000 \mathrm{~cm}^{-1}$, which are specific peaks for cellulose (Bodirlau et al. 2010). The intensities of transmission bands at 1000 to $1200 \mathrm{~cm}^{-1}$ were lower for pretreated samples than raw OPEFB, indicating the increase in relative cellulose content in the biomass.

The lowest transmission intensity occurred after sequential pretreatment of $\mathrm{Na}_{3} \mathrm{PO}_{4} .12 \mathrm{H}_{2} \mathrm{O}-\mathrm{ZnCl}_{2}$. The results were inconsistent with previous results in Table 1, in which cellulose content in the samples increased after pretreatment. Nevertheless, the peak intensity of FTIR spectra was not adequate to represent absolute value for any kind of quantitative analysis. 


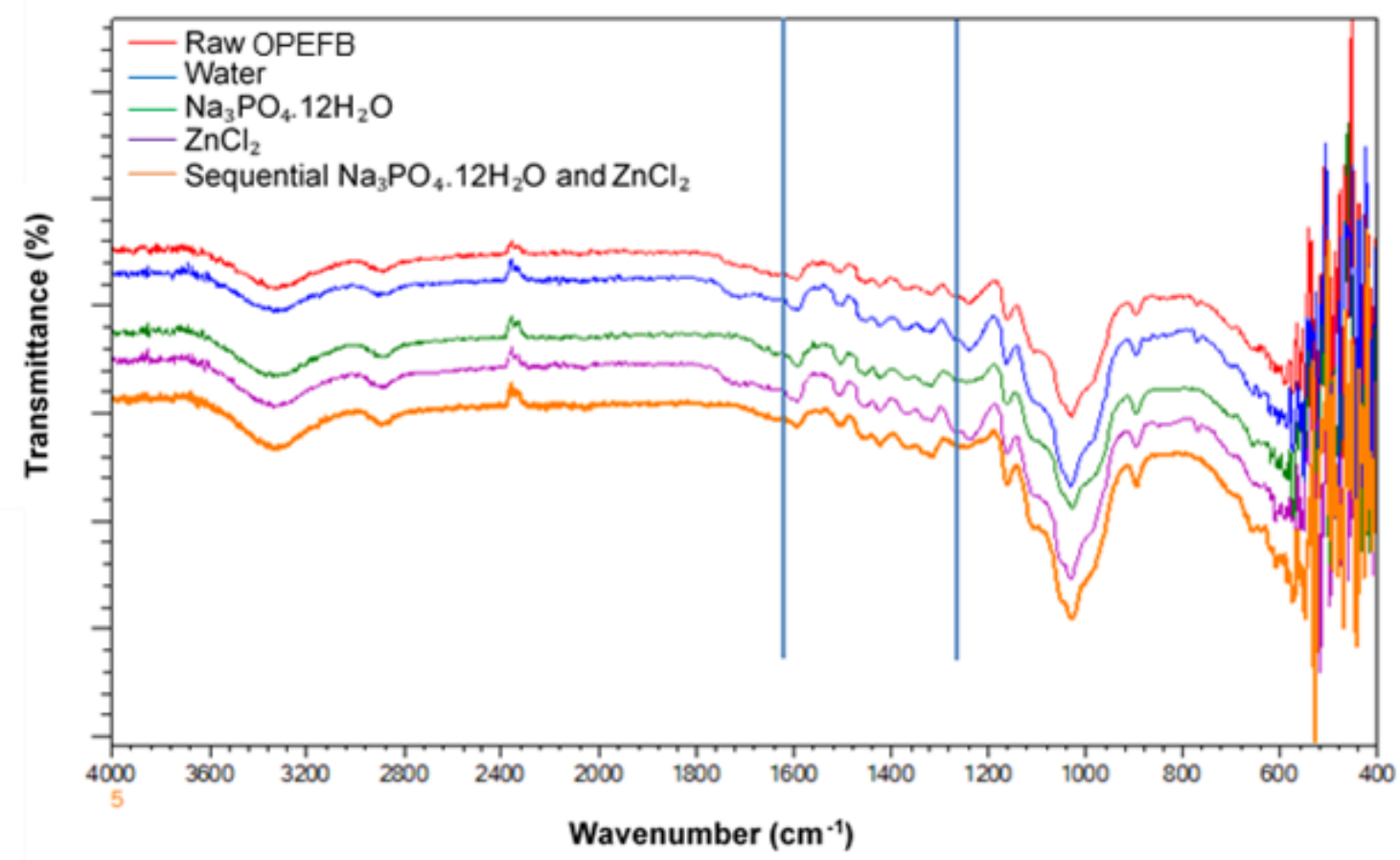

Fig. 1. FT-IR spectra of raw and pretreated OPEFB

The lignin building block is represented by the discerned band of 1641 to $1635 \mathrm{~cm}^{-1}$ (Sun et al. 2003). Lignin of EFB fiber consists of guaiacyl propane (G) and syringyl propane units (S), which contain one and two methoxy groups respectively (Sun et al. 2003; Lai and Idris 2013). The typical band for guaiacyl propane was at $1245 \mathrm{~cm}^{-1}$ (Lai and Idris 2013). The band at $1250 \mathrm{~cm}^{-1}$ vanished in spectra of sequential $\mathrm{Na}_{3} \mathrm{PO}_{4} .12 \mathrm{H}_{2} \mathrm{O}-$ $\mathrm{ZnCl}_{2}$ treated OPEFB and $\mathrm{Na}_{3} \mathrm{PO}_{4} \cdot 12 \mathrm{H}_{2} \mathrm{O}$ treated OPEFB compared with the stronger transmittance signal in spectra of untreated sample, indicating that lignin was partially or fully removed during the pretreatment using alkali salt. Similar to the untreated OPEFB, $\mathrm{ZnCl}_{2}$ treated OPEFB showed a strong signal at band $1245 \mathrm{~cm}^{-1}$, indicating that there was poor removal of lignin by $\mathrm{ZnCl}_{2}$ pretreatment, as previously presented in Table 1 .

\section{Crystallinity Analysis}

The crystallinity of biomass has a significant effect to the subsequent enzymatic hydrolysis of cellulosic substrate (Abdul et al. 2016; Wei et al. 2019). Thus, X-ray diffraction patterns of samples in Fig. 2 were used to examine the influence of different pretreatment methods on crystallinity changes in the various OPEFB samples. X-ray diffraction of raw OPEFB and standard cellulose were included for comparison. All samples displayed two diffraction peaks at 15 to $16^{\circ}$ (secondary peak) and 21 to $22^{\circ}$ (primary peak), which are specific for diffraction intensities of the amorphous zone and diffraction intensity of crystalline regions, respectively. The results of crystallinity index (Crl) for various pretreated samples, untreated OPEFB, and standard cellulose (Table 2) were calculated based on the Seagel calculation. The diffractograms of treated and nontreated OPEFB were found to match with standard cellulose (SigmaCell) with regards to the presence of cellulose in each sample. However, the intensity of OPEFB crystallinity was lower than the cellulose reference. 


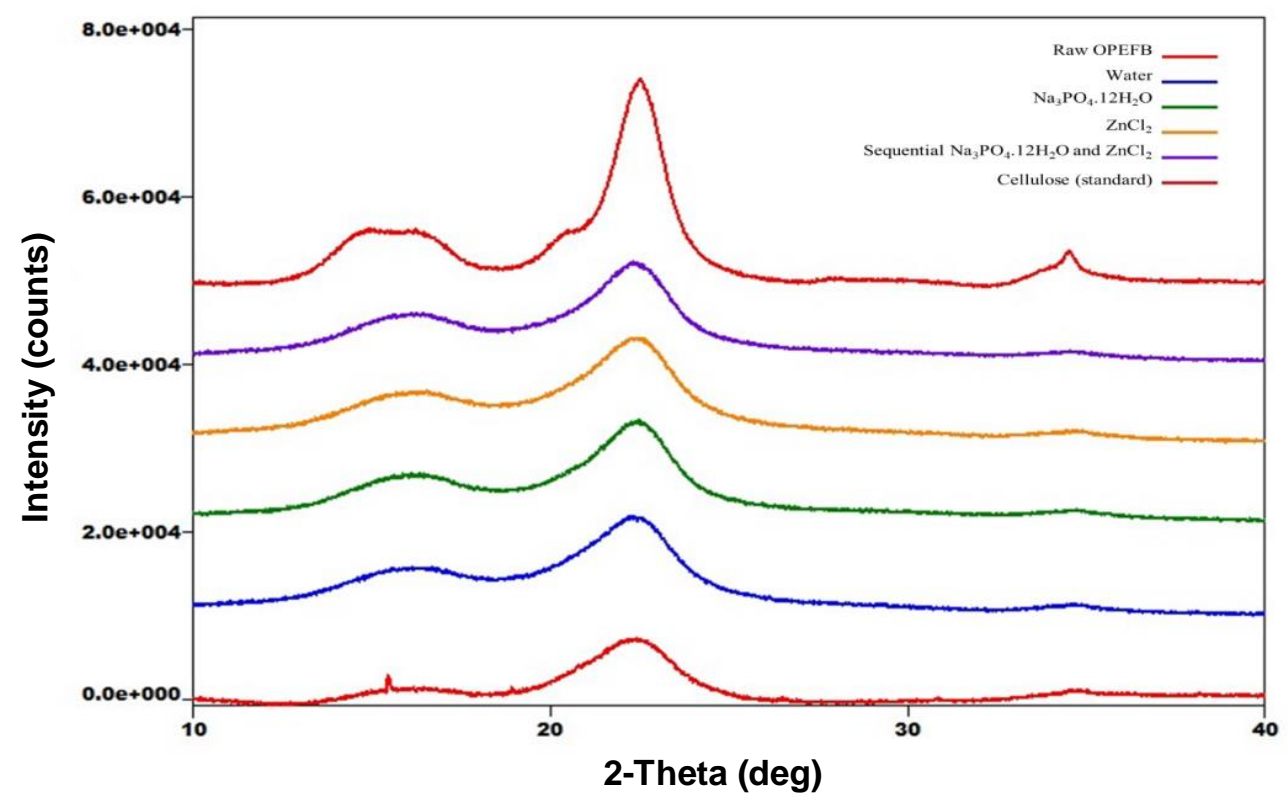

Fig. 2. XRD patterns standard cellulose, untreated sample and pretreated OPEFB

The CrI of untreated OPEFB was $22.8 \%$, and this value increased to $31.8 \%, 32.5 \%$, $32.0 \%$, and $33.5 \%$ after it was subjected to hot water pretreatment, $\mathrm{Na}_{3} \mathrm{PO}_{4} .12 \mathrm{H}_{2} \mathrm{O}, \mathrm{ZnCl}_{2}$, and sequential $\mathrm{Na}_{3} \mathrm{PO}_{4} \cdot 12 \mathrm{H}_{2} \mathrm{O}-\mathrm{ZnCl}_{2}$ pretreatment, respectively. The $\mathrm{Crl}$ of all various pretreated samples were significantly higher than untreated OPEFB. As shown in Table 2, the highest $\mathrm{CrI}$ value of OPEFB was found in sequential $\mathrm{Na}_{3} \mathrm{PO}_{4} .12 \mathrm{H}_{2} \mathrm{O}-\mathrm{ZnCl}_{2}$ pretreated OPEFB followed by single treatment using $\mathrm{Na}_{3} \mathrm{PO}_{4} .12 \mathrm{H}_{2} \mathrm{O}, \mathrm{ZnCl}_{2}$, and water. The increases in $\mathrm{Crl}$ value after pretreatments were attributed to the removal of amorphous fractions such as hemicellulose or lignin. The removal of amorphous substances in the biomass, mostly hemicellulose exposed the crystalline cellulose core resulting in an increase in CrI and glucan content in the pretreated solid fraction of OPEFB. Previous studies also reported an increase in CrI values after biomass pretreatment (Abdul et al. 2016; Wei et al. 2019).

Table 2. Crystallinity Index of Raw and Different Pretreated OPEFB

\begin{tabular}{|c|c|}
\hline Samples & $\mathrm{Crl}(\%)$ \\
\hline Raw OPEFB-Untreated & 22.76 \\
\hline Water pretreatment & 31.78 \\
\hline $\mathrm{Na}_{3} \mathrm{PO}_{4} .12 \mathrm{H}_{2} \mathrm{O}$ & 32.48 \\
\hline $\mathrm{ZnCl}_{2}$ & 32.04 \\
\hline $\begin{array}{c}\text { Sequential pretreatment of } \\
\mathrm{Na}_{3} \mathrm{PO}_{4} .12 \mathrm{H}_{2} \mathrm{O}-\mathrm{ZnCl}_{2}\end{array}$ & 33.52 \\
\hline Cellulose & 56.56 \\
\hline
\end{tabular}

\section{Morphology Analysis of OPEFB}

The delignification results of sequential $\mathrm{Na}_{3} \mathrm{PO}_{4} \cdot 12 \mathrm{H}_{2} \mathrm{O}-\mathrm{ZnCl}_{2}$ pretreated OPEFB was outstanding compared with the other pretreatment methods, and thus its morphological structure was further analysed. Figure 3 depicts FESEM images for both untreated OPEFB and sequential $\mathrm{Na}_{3} \mathrm{PO}_{4} .12 \mathrm{H}_{2} \mathrm{O}-\mathrm{ZnCl}_{2}$ pretreated OPEFB. 

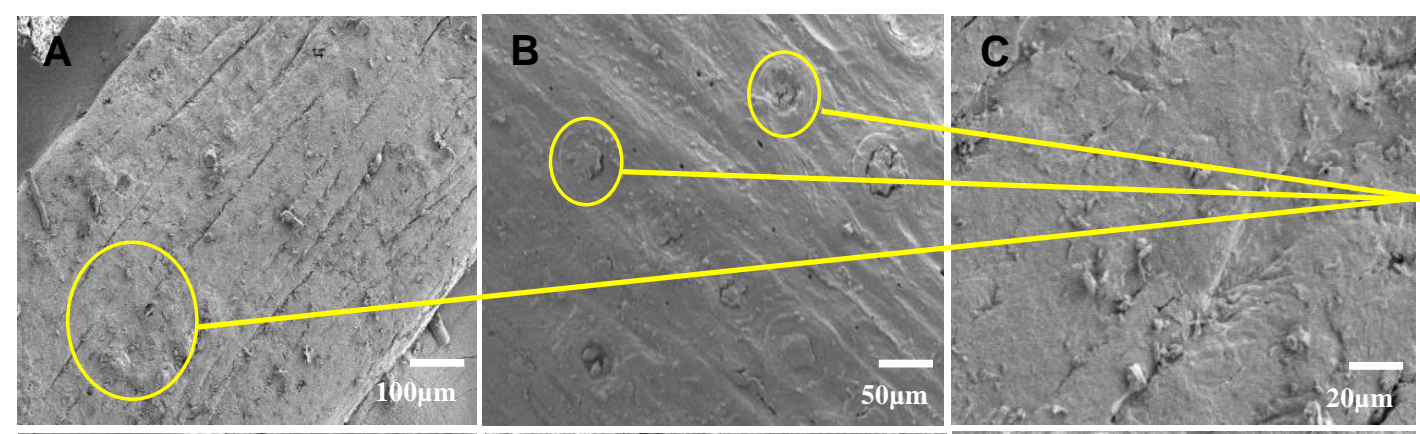

Silica
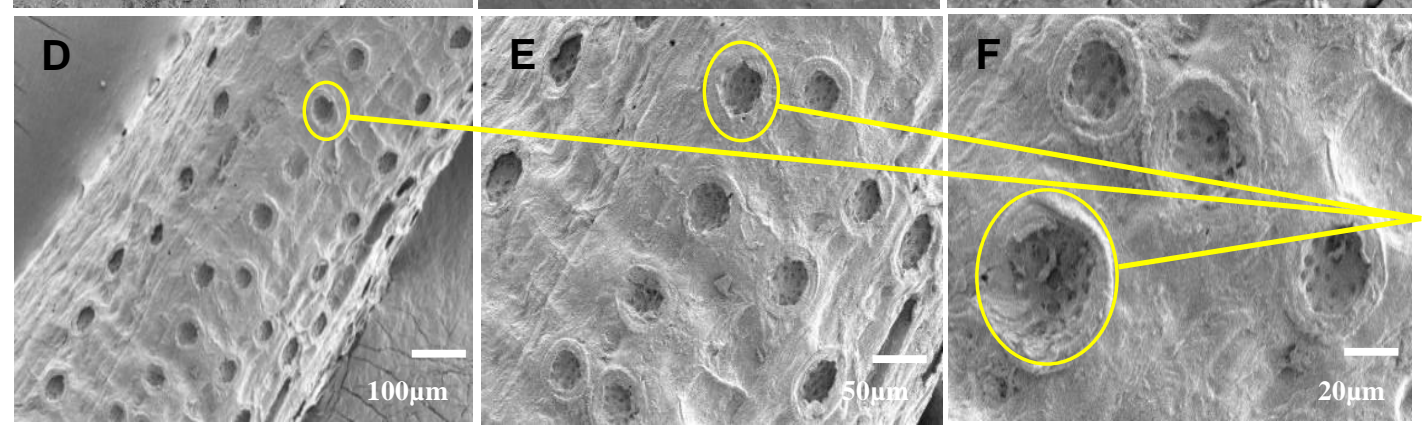

Cavities

Fig. 3. FESEM images of OPEFB fiber. (a-c) Untreated OPEFB (d-f) Sequential $\mathrm{Na}_{3} \mathrm{PO}_{4} \cdot 12 \mathrm{H}_{2} \mathrm{O}$ treated OPEFB

The structure of raw EFB changed significantly as a result of pretreatment. The micrographs in Figs. 3a, b, and $\mathrm{c}$ show the surface of raw OPEFB at different magnifications. Raw OPEFB has a rough surface, with many circular-shaped protruding silica entities in uniform craters. Abdul et al. (2016) reported the existence of protruding silica entities on the waxy epidermal layer of OPEFB. The presence of silica entities in untreated OPEFB gives the high crystallinity structure in cellulose. Thus, pretreatment performed has eliminated lignin and silica entities, which subsequently reduces the crystalline structure to a more amorphous structure, thus promoting the rate of hydrolysis in sugar production.

The FESEM images for pretreated OPEFB are shown in Figs. 3d, e, and f. Upon sequential $\mathrm{Na}_{3} \mathrm{PO}_{4} .12 \mathrm{H}_{2} \mathrm{O}-\mathrm{ZnCl}_{2}$ pre-treatment, the silica entities were dislodged from the surfaces of the OPEFB fibers, leaving circular cavities. These circular cavities lead to the opening of the siliceous pathway, further exposing the amorphous region of the fibres and improving enzymatic hydrolysis performance.

\section{Enzymatic Saccharification of OPEFB}

Enzymatic hydrolysis on the various pretreated OPEFB was performed and evaluated based on TRS yield basis. During the saccharification, OPEFB obtained from pretreatment methods were used as a substrate and mixed with a cellulase enzyme blend (20 FPU). A control experiment of enzymatic hydrolysis using untreated OPEFB was also performed in the same conditions. Figure 4 summarizes the effect of different pretreatment methods on TRS yield. The total fermentable sugar yield of untreated OPEFB was only $0.14 \mathrm{~g} / \mathrm{g}$ after $72 \mathrm{~h}$ of hydrolysis time. This finding on poor enzymatic digestion of unpretreated OPEFB was in accordance with previous report (Abdul et al. 2016). The pretreated OPEFB exhibited significantly higher TRS yields than untreated OPEFB. It was also noted that higher yield of TRS was achieved with increased hydrolysis times. This 
phenomenon implied that OPEFB digestibility was improved after various pretreatments. Such improvement of yield of reducing sugars could be explained in terms of the removal of physical barriers such as silica bodies, lignin, and hemicellulose, producing weaker intermolecular bonds. The characteristics of the pretreated OPEFB offered better access of the sugar components (cellulose and hemicellulose) to hydrolytic enzymes. However, different types of pretreatment showed various degrees of improvement. A single $\mathrm{ZnCl}_{2}$ pretreatment yielded the lowest TRS, with only $0.22 \mathrm{~g} / \mathrm{g}$ OPEFB. The use of hot liquid water during pretreatment has yielded insignificant improvement as low TRS accumulation was recorded. However, the TRS yield after $\mathrm{Na}_{3} \mathrm{PO}_{4} \cdot 12 \mathrm{H}_{2} \mathrm{O}$ pretreatment was obviously higher than that in $\mathrm{ZnCl}_{2}$ single pretreatment $(0.8 \mathrm{~g} / \mathrm{g}$ OPEFB). The used of alkali salt $\left(\mathrm{Na}_{3} \mathrm{PO}_{4} .12 \mathrm{H}_{2} \mathrm{O}\right)$ in the pretreatment of OPEFB gave higher final total sugar recovery yield at the end of enzymatic saccharification compared with metal salt $\left(\mathrm{ZnCl}_{2}\right)$ pretreatment. The lower reducing sugar in the $\mathrm{ZnCl}_{2}$ pretreated sample could be ascribed to its higher lignin content after pretreatment, which was confirmed by the compositional report in Table 1. As depicted in Fig. 4, the use $\mathrm{Na}_{3} \mathrm{PO}_{4} \cdot 12 \mathrm{H}_{2} \mathrm{O}$ and $\mathrm{ZnCl}_{2}$ in sequential order yielded the highest TRS with $0.97 \mathrm{~g} / \mathrm{g}$ OPEFB, suggesting that sequential pretreatment of $\mathrm{Na}_{3} \mathrm{PO}_{4} \cdot 12 \mathrm{H}_{2} \mathrm{O}-\mathrm{ZnCl}_{2}$ is the most efficient pretreatment method. These findings agree with those in Table 1 and with previous findings (Sewsynker-Sukai and Kana 2017) using sequential alkali and metal salt to treat corn cobs.

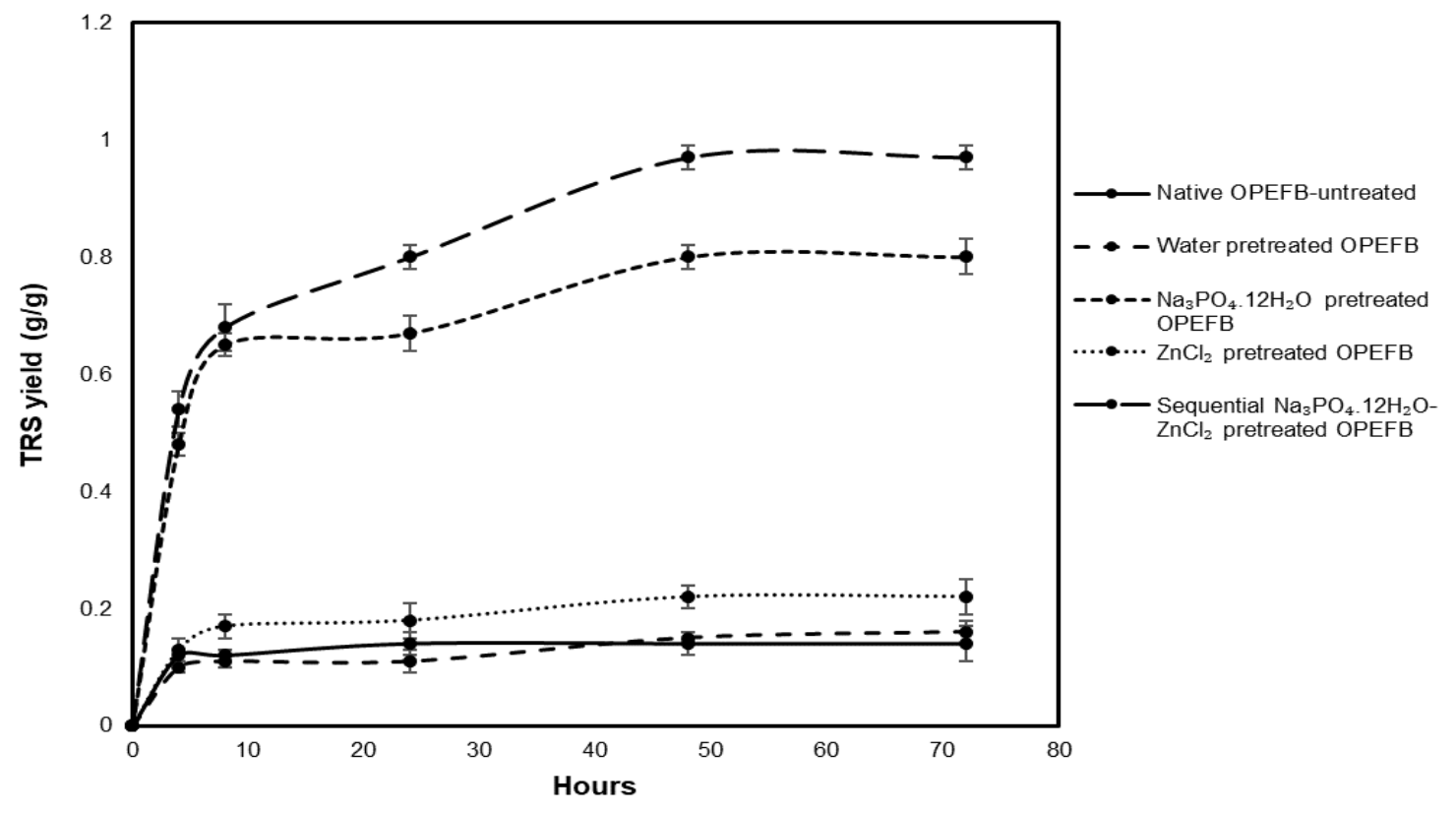

Fig. 4. Enzymatic hydrolysis profile of untreated and pretreated OPEFB

Table 3 shows the total reducing sugar yield obtained from OPEFB using various pretreatment methods found in the literature. The assessment of the pretreatment method used here and the previous studies are comparable, as the reducing sugar yields reported in previous pretreatment studies were performed under optimized enzymatic hydrolysis and they use OPEFB as substrates.

Higher total reducing sugar yields with 4.8-fold increase was obtained using sequential pretreatment using $\left(\mathrm{Na}_{3} \mathrm{PO}_{4} .12 \mathrm{H}_{2} \mathrm{O}\right)$ and zinc chloride $\left(\mathrm{ZnCl}_{2}\right)$ compared to the study conducted by Shamsudin et al. (2012), which used steam pretreatment on OPEFB. 
Sai and Lee et al. (2019) attempted to enhance the cellulose accessibility by using acidbased deep eutectic solvent in pretreatment of OPEFB, and the sugar yield obtained was only 46\%. Similarly, Abdul et al. (2016) and Palamae (2017) when using pretreatment of ammonia fibre expansion and peracetic acid- alkaline peroxide achieved $44 \%$ and $34 \%$ total reducing sugar, respectively. Thamsee et al. (2019) reported a comparable total reducing sugar yield $(0.9 \mathrm{~g} / \mathrm{g})$ was obtained using superheated steam explosion and steam alkali. However, the delignification process used a combination of superheated steam explosion and steam alkali at high temperature which are energy intensive processes. Therefore, it can be concluded that the optimized sequential inorganic salt pretreatment in the present study is an attractive alternative pretreatment method to be considered when dealing with OPEFB.

Table 3. Reducing Sugar Yield Obtained from OPEFB using Various Pretreatment Methods

\begin{tabular}{|c|c|c|c|}
\hline Substrate & Pretreatment conditions & $\begin{array}{l}\text { TRS yield } \\
(\mathrm{g} / \mathrm{g})\end{array}$ & References \\
\hline OPEFB & $\begin{array}{l}\text { Steam pretreatment (palm oil mill boiler) } \\
0.28 \mathrm{MPa}, 140^{\circ} \mathrm{C}, 15 \mathrm{~min}\end{array}$ & 0.20 & $\begin{array}{l}\text { Shamsudin et } \\
\text { al. (2012) }\end{array}$ \\
\hline OPEFB & $\begin{array}{l}\text { Deep eutectic solvent (choline chloride-lactic } \\
\text { acid) soaking. } \\
\text { Solid-to-liquid ratio of } 1: 10,100^{\circ} \mathrm{C}, 1 \mathrm{~h}\end{array}$ & 0.51 & $\begin{array}{l}\text { Sai and Lee } \\
(2019)\end{array}$ \\
\hline OPEFB & $\begin{array}{l}\text { Ammonia fibre expansion pretreatment } \\
\text { Ammonia to biomass loading } 1: 1,135^{\circ} \mathrm{C}, 35-50 \\
\text { bar, } 45 \text { min }\end{array}$ & 0.53 & $\begin{array}{l}\text { Abdul et al. } \\
2016\end{array}$ \\
\hline OPEFB & $\begin{array}{l}\text { Sequential two-step treatment with peracetic } \\
\text { acid and alkaline peroxide. Peracetic acid } \\
\text { soaking }\left(35^{\circ} \mathrm{C}, 9 \mathrm{~h}\right) \text { followed by alkaline } \\
\text { peroxide pretreatment }\left(4 \% \mathrm{NaOH}, 20^{\circ} \mathrm{C}, 12 \mathrm{~h}\right)\end{array}$ & 0.63 & $\begin{array}{l}\text { Palamae et al. } \\
(2017)\end{array}$ \\
\hline OPEFB & $\begin{array}{l}\text { Sequential superheated steam explosion and } \\
\text { alkaline autoclaving pretreatment. } \\
\text { The superheated steam explosion pretreatment } \\
\left(180^{\circ} \mathrm{C}, 5 \mathrm{~min}\right) \text { followed by alkaline steam } \\
\text { treatment using autoclave }(15 \%(\mathrm{w} / \mathrm{v}) \mathrm{NaOH} \text {, } \\
\text { Solid-to-liquid ratio of } 1: 10,121^{\circ} \mathrm{C}, 40 \mathrm{~min}\end{array}$ & 0.90 & $\begin{array}{l}\text { Thamsee et al. } \\
(2019)\end{array}$ \\
\hline OPEFB & $\begin{array}{l}\text { Sequential pretreatment of alkaline salt and } \\
\text { metal salt } \\
15 \% \mathrm{Na}_{3} \mathrm{PO}_{4} .12 \mathrm{H}_{2} \mathrm{O}, 5 \% \mathrm{ZnCl}_{2} \text {, Solid-to-liquid } \\
\text { ratio of } 1: 10,121^{\circ} \mathrm{C}, 1 \mathrm{~h}\end{array}$ & 0.97 & Current study \\
\hline
\end{tabular}

\section{Effect of Pretreatment Conditions}

Important factors such as $\mathrm{Na}_{3} \mathrm{PO}_{4} .12 \mathrm{H}_{2} \mathrm{O}$ concentration, biomass loading, and pretreatment time on the performance of hydrolysis were evaluated. Saccharification yields of TRS released upon the completion of hydrolysis were used as indices in determining its optimum condition. The effect of $\mathrm{Na}_{3} \mathrm{PO}_{4} \cdot 12 \mathrm{H}_{2} \mathrm{O}$ concentration on the pretreatment processes using various concentrations of alkali salt including 5, 10, 15, and $20 \%$ are depicted in Fig. 5. As shown in Fig. 5a, the $\mathrm{Na}_{3} \mathrm{PO}_{4} \cdot 12 \mathrm{H}_{2} \mathrm{O}$ concentration had an obvious impact to the effectiveness of pretreatment process. 

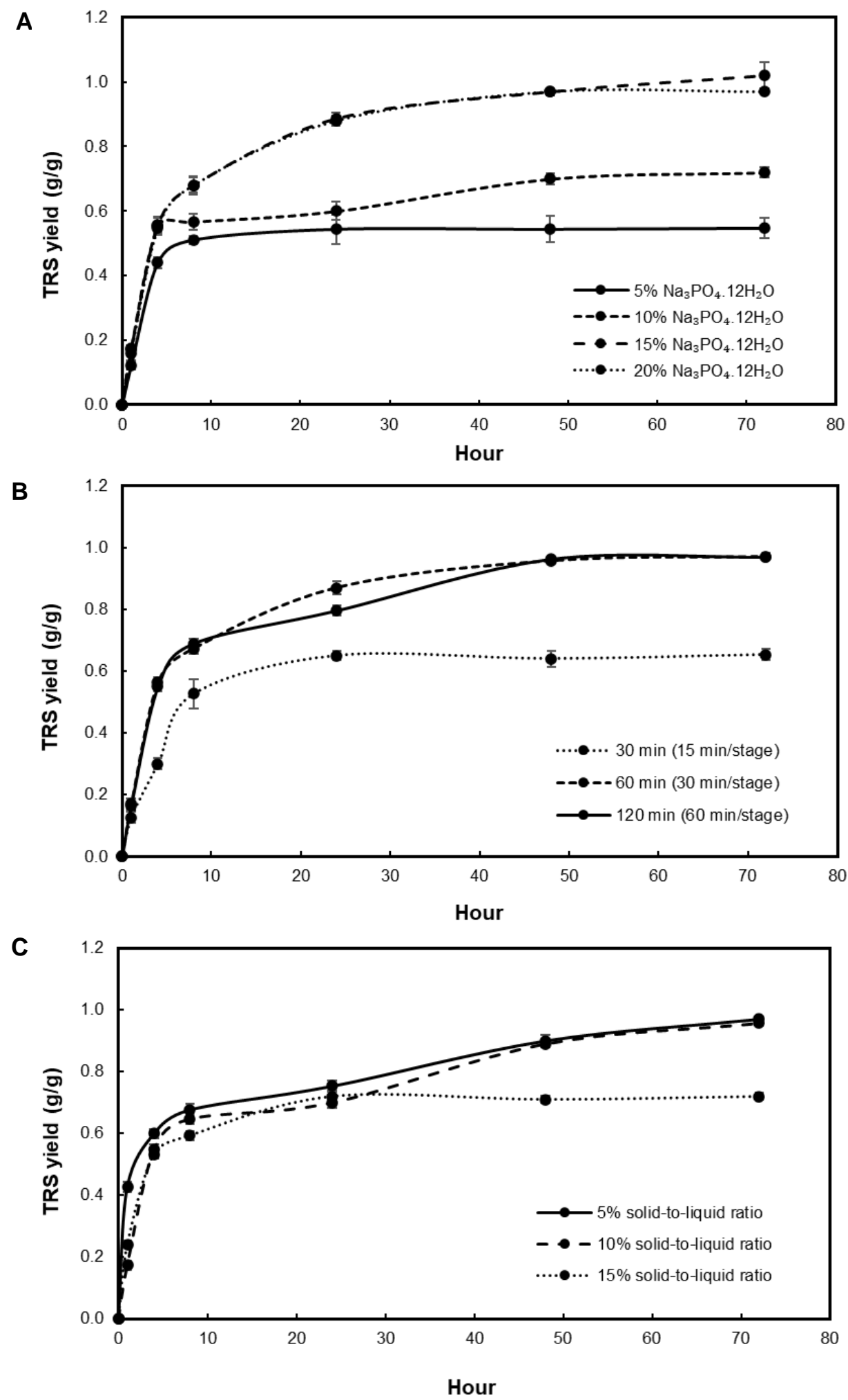

Fig. 5. Effect of pretreatment conditions on enzymatic hydrolysis yield of OPEFB. a) Effect of $\mathrm{Na}_{3} \mathrm{PO}_{4} .12 \mathrm{H}_{2} \mathrm{O}$ concentration on the total reducing sugar yield; the pretreatment was carried out at $10 \%$ of biomass loading within 60 min of pretreatment. b) Effect of pretreatment time on the enzymatic hydrolysis of OPEFB; the pretreatment was carried out using $15 \%$ of $\mathrm{Na}_{3} \mathrm{PO}_{4} .12 \mathrm{H}_{2} \mathrm{O}$ at $10 \%$ solid to liquid ratio. c) Effect of solid to liquid ratio on enzymatic hydrolysis; pretreatment was carried out for 60 min using $15 \%$ of $\mathrm{Na}_{3} \mathrm{PO}_{4} .12 \mathrm{H}_{2} \mathrm{O}$. 
A low TRS yield of $0.55 \mathrm{~g} / \mathrm{g}$ was obtained when the pretreatment was conducted using low concentration $\mathrm{Na}_{3} \mathrm{PO}_{4} .12 \mathrm{H}_{2} \mathrm{O}$ (5\%). However, when the $\mathrm{Na}_{3} \mathrm{PO}_{4} .12 \mathrm{H}_{2} \mathrm{O}$ concentration was increased to $10 \%$ and $15 \%$, the TRS yield increased to 0.7 and $0.97 \mathrm{~g} / \mathrm{g}$, respectively. Generally, the use of stronger alkali salt concentration creates an alkaline environment in the pretreatment solution, which could remove lignin effectively. However, further increases in $\mathrm{Na}_{3} \mathrm{PO}_{4} .12 \mathrm{H}_{2} \mathrm{O}$ concentration to $20 \%$ was statistically insignificant, as shown by the two-way ANOVA; the final concentration of TRS remains the same at 0.97 g/g. Therefore, $15 \%$ of $\mathrm{Na}_{3} \mathrm{PO}_{4} \cdot 12 \mathrm{H}_{2} \mathrm{O}$ concentration was the optimum dosage of alkali salt. The optimum point of $\mathrm{Na}_{3} \mathrm{PO}_{4} \cdot 12 \mathrm{H}_{2} \mathrm{O}$ concentration $(15 \%)$ used in this study was slightly higher than that recommended by Sewsynker-Sukai and Gueguim Kana (2018). Figure $5 \mathrm{~b}$ shows the time course of hydrolysis yield of pretreated OPEFB at different pretreatment times. The profile of enzymatic hydrolysis yield showed that the pretreatment time plays an important role as the sugar released is very much dependent to the pretreatment time. By applying 30 min of pretreatment time, maximum TRS yield reached up to $0.64 \mathrm{~g} / \mathrm{g}$. Prolonging the pretreatment time to $60 \mathrm{~min}$ resulted in the highest enzymatic hydrolysis yield $(0.97 \mathrm{~g} / \mathrm{g})$, but extending the pretreatment time to $120 \mathrm{~min}$ did not further improve the enzymatic hydrolysis yield. Two-way ANOVA suggested no significant difference between the TRS yield when the pretreatment time of $60 \mathrm{~min}$ and $120 \mathrm{~min}$. Hence, the 60 min pretreatment time was adequate to enhance the enzymatic hydrolysis.

The maximum sugar yield of $0.97 \mathrm{~g} / \mathrm{g}$ and delignification rate of $58.8 \%$ obtained from this study using OPEFB as a substrate was comparable with that from corncobs reported by Sewsynker-Sukai and Kana (2017). However, pretreatment process time for the latter was shorter $(30 \mathrm{~min})$. The differences in optimum pretreatment time may be attributed to the variety of chemicals constituent of OPEFB used and its compact structure. The higher lignin content of $21.1 \%$ in OPEFB may cause slower diffusion of the inorganic salt solution, thus requiring a longer pretreatment time.

Biomass loading during the pretreatment is another crucial factor. In a practical pretreatment process, the high biomass-liquid ratio would be problem in terms of ensuring constant temperature and homogeneous heating, while the low ratio reflects increase in the pretreatment cost. Therefore, it was necessary to choose a suitable biomass to liquid ratio. As shown in the Fig. 5c, the enzymatic hydrolysis yield at 5\% of biomass-liquid ratio reached $97 \%$ within $48 \mathrm{~h}$. The TRS yield remained at $97 \%$ when the biomass loading was further increased to $10 \%$. A further increase in feeding ratio to $15 \%$ exhibited substantial decrease in TRS yield to $0.72(\mathrm{~g} / \mathrm{g})$. The high biomass loading used during pretreatment caused mass transfer effect as the biomass fraction could not be dissolved and hydrolysed completely. However, low biomass loading makes the process nonviable and uneconomical. The solid-liquid ratio of $10 \%$ was recommended by two-way ANOVA for effective enzymatic hydrolysis in the sequential inorganic pretreatment of OPEFB. Previous work on solid to liquid ratio showed that the maximum TRS yield is obtained by using 5 to $15 \%$ of solid to liquid ratio (Qing et al. 2016; Sewsynker-Sukai and Kana 2018) when dealing with corn cobs and bamboo shoot shells.

\section{Recycle Experiments}

One of the hindrances to effective delignification of OPEFB using a combination of alkaline and metal salt is the large amount of black liquor produced during the pretreatment process. The spent liquid after pretreatment has a high alkalinity and consists of polyphenolic compounds, which include lignin residues, degradation products, and inorganic constituents (Qing et al. 2016; Zhou et al. 2019). Therefore, the black liquor 
must be treated, but processing large quantities of spent liquors requires high treatment cost, which makes the overall production process become uncompetitive.

Thus, a strategy was devised to reuse the black liquor to reduce the overall production cost and to protect the environment to the maximum extent. The recycle performance of the spent liquor was evaluated on the basis of TRS yield obtained from the subsequent enzymatic hydrolysis process. Figure 6a shows that without $\mathrm{pH}$ adjustment, a downward trend was observed in relationship between cycle number of spent liquor and the yield of reducing sugar.
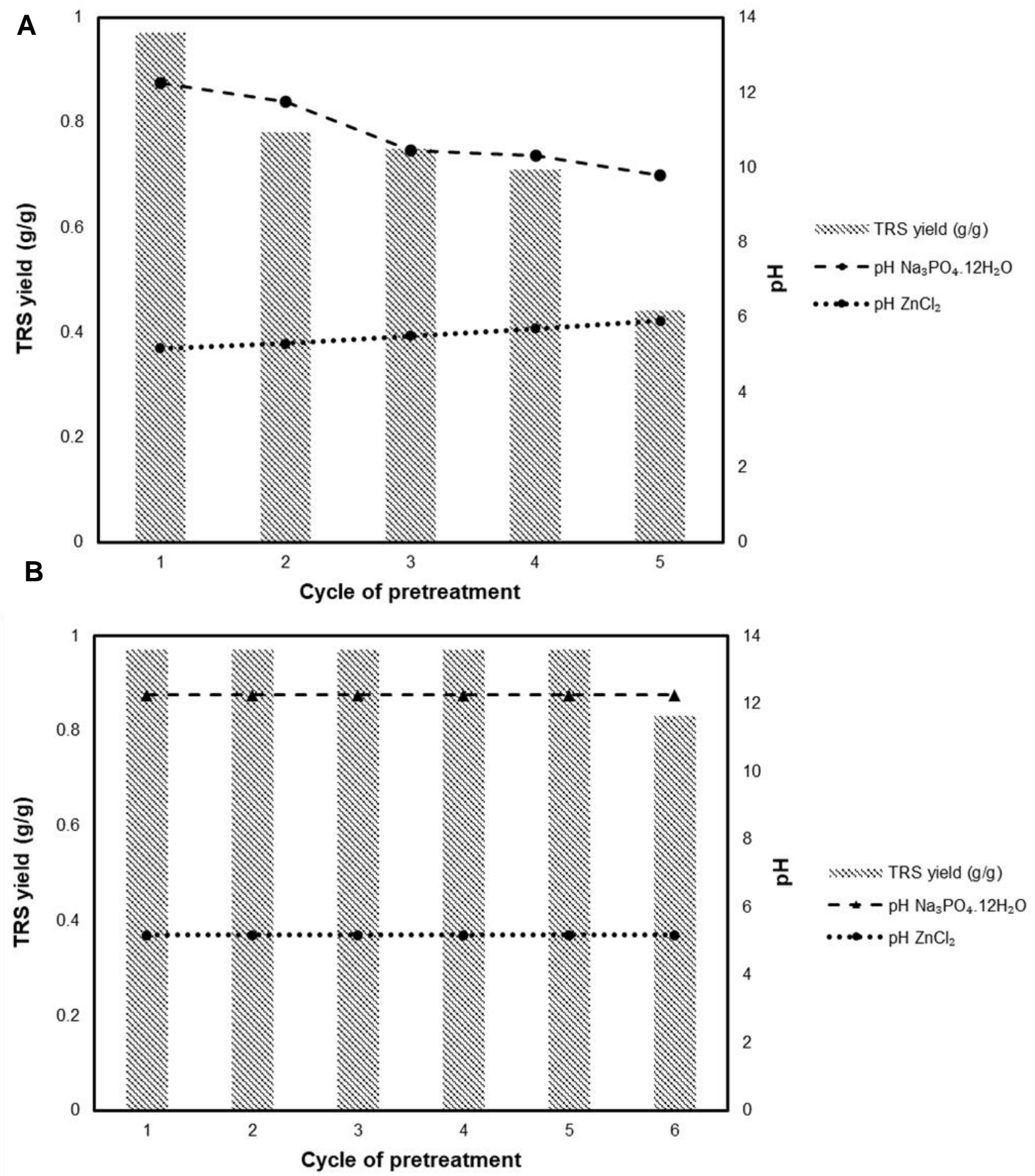

Fig. 6. Recycling Experiments using spent liquor produced: (a) without $\mathrm{pH}$ adjustment (b) with $\mathrm{pH}$ adjustment. 
When the number of cycles was increased, the yield of TRS gradually decreased. At the $1^{\text {st }}, 2^{\text {nd }}$, and $3^{\text {rd }}$ cycles, the TRS yields was reduced to $0.78,0.75$, and $0.71 \mathrm{~g} / \mathrm{g}$, respectively, which represented $19.6,22.7$, and $26.8 \%$ less than its initial value. The lowest sugar yield of $0.41 \mathrm{~g} / \mathrm{g}$ was obtained after recycling for 4 times, which corresponds to less than $57 \%$ of TRS value at initial cycle. The $\mathrm{pH}$ value of both spent alkaline and metal salt liquor changed considerably after each cycle. However, only small changes in $\mathrm{pH}$ value from spent $\mathrm{ZnCl}_{2}$ were noticed. Therefore, the reason for the reduction in the efficiency of pretreatment after being recycled for many times was due to the $\mathrm{pH}$ changes in spent liquid. A similar finding was reported by Qing et al. (2016).

The decrease in $\mathrm{pH}$ value in alkali salt may be attributed to the gradual accumulation of degradation products, including organic acid, lignin, and acetic acid, which were produced during the pretreatment process (Qing et al. 2016). Moreover, an alkaline $\mathrm{pH}$ was essential in delignification, as the alkaline environment facilitated the oxidation of ethylenic double bonds in the side chains of lignin phenylpropane units (Geng et al. 2014). In order to reuse the spent liquor again, the $\mathrm{pH}$ of the recycled alkaline salt was adjusted to the appropriate value by adding $5 \mathrm{M} \mathrm{NaOH}$, and the results are shown in Fig. 5b. The recycling performance of the spent pretreatment liquid with $\mathrm{pH}$ adjustment was similar to that of OPEFB treated with fresh pretreatment liquid for 4 cycles. However, when the black liquor was reused for the $5^{\text {th }}$ time, the TRS yield decreased from 0.97 to $0.83 \mathrm{~g} / \mathrm{g}$, which accounted for $14.43 \%$ of the total decline.

\section{CONCLUSIONS}

1. This study demonstrated the effectiveness of inorganic salt pretreatment to enhance the enzymatic hydrolysis, delignification, and structural features of OPEFB.

2. The dual effect of sequential $\mathrm{Na}_{3} \mathrm{PO}_{4} \cdot 12 \mathrm{H}_{2} \mathrm{O}$ and $\mathrm{ZnCl}_{2}$ had enhanced the breakdown of the recalcitrant structure, thus improving the enzymatic saccharification of OPEFB.

3. With optimum operating pretreatment condition $(15 \%) \mathrm{Na}_{3} \mathrm{PO}_{4} .12 \mathrm{H}_{2} \mathrm{O}, 60 \mathrm{~min}(30 \mathrm{~min}$ per stage) pretreatment time, and $10 \%$ solid to liquid ratio, the sequential $\mathrm{Na}_{3} \mathrm{PO}_{4} .12 \mathrm{H}_{2} \mathrm{O}-\mathrm{ZnCl}_{2}$ pretreated OPEFB was able to produce 7-folds increased yield of reducing sugar $(0.97 \mathrm{~g} / \mathrm{g})$ compared to untreated sample.

4. The spent liquor produced can be recycled at least 4 times with minor pH adjustments without affecting the sugar yields, thus making it an attractive alternative pretreatment method for OPEFB.

\section{ACKNOWLEDGMENTS}

The authors thank the Malaysia Ministry of Higher Education (R.J130000.7851.5F244 and R.J130000.7851.4L703) for providing the funds for this research. 


\section{REFERENCES CITED}

Abdul, P. M., Jahim, J. M., Harun, S., Markom, M., Lutpi, N. A., Hassan, O., and Nor, M.T. M. (2016). "Effects of changes in chemical and structural characteristic of ammonia fibre expansion (AFEX) pretreated oil palm empty fruit bunch fibre on enzymatic saccharification and fermentability for biohydrogen," Bioresource Technology 211, 200-208. DOI: 10.1016/j.biortech.2016.02.135

Akhtar, J., Hassan, N., Idris, A., and Ngadiman, N. H. A. (2019). "Optimization of simultaneous saccharification and fermentation process conditions for the production of succinic acid from oil palm empty fruit bunches," Journal of Wood Chemistry and Technology 1-10. DOI: 10.1080/02773813.2019.1697294

Akhtar, J., Teo, C. L., Lai, L. W., Hassan, N., Idris, A., and Aziz, R. A. (2014). 'Factors affecting delignification of oil palm empty fruit bunch by microwave-assisted dilute acid/alkali pretreatment," BioResources 10(1), 588-596. DOI: 10.15376/biores.10.1.588-596

Alam, M. A., Yuan, T., Xiong, W., Zhang, B., Lv, Y., and Xu, J. (2019). "Process optimization for the production of high-concentration ethanol with Scenedesmus raciborskii biomass," Bioresource Technology 294, 122219. DOI: 10.1016/j.biortech.2019.122219

Bodirlau, R., Teaca, C. A., and Spiridon, I. (2010). "Influence of ionic liquid on hydrolyzed cellulose material: FT-IR spectroscopy and TG-DTG-DSC analysis," International Journal of Polymer Analysis and Characterization 15(7), 460-469. DOI:10.1080/1023666X.2010.510112

Bukhari, N. A., Loh, S. K., Nasrin, A. B., Luthfi, A. A. I., Harun, S., Abdul, P. M., and Jahim, J. M. (2019). "Compatibility of utilising nitrogen-rich oil palm trunk sap for succinic acid fermentation by Actinobacillus succinogenes 130Z," Bioresource Technology, 293, 122085. DOI: 10.1016/j.biortech.2019.122085

Chen, H., Huo, W., Wang, B., Wang, Y., Wen, H., Cai, D., and Qin, P. (2019). 'L-lactic acid production by simultaneous saccharification and fermentation of dilute ethylediamine pre-treated rice straw," Industrial Crops and Products 141, 111749. DOI: $10.1016 /$ j.indcrop.2019.111749

Chen, Z., and Wan, C. (2018). "Ultrafast fractionation of lignocellulosic biomass by microwave-assisted deep eutectic solvent pretreatment," Bioresource Technology 250, 532-537. DOI: 10.1016/j.biortech.2017.11.066

Cheng, M. H., Huang, H., Dien, B. S., and Singh, V. (2019). "The costs of sugar production from different feedstocks and processing technologies," Biofuels, Bioproducts and Biorefining 13(3), 723-739. DOI: 10.1002/bbb.1976

Da Silva Machado, A., and Ferraz, A. (2017). "Biological pretreatment of sugarcane bagasse with basidiomycetes producing varied patterns of biodegradation," Bioresource Technology 225, 17-22. DOI: 10.1016/j.biortech.2016.11.053

Fehér, A., Fehér, C., Rozbach, M., Rácz, G., Fekete, M., Hegedűs, L., and Barta, Z. (2018). "Treatments of lignocellulosic hydrolysates and continuous-flow hydrogenation of xylose to xylitol," Chemical Engineering and Technology 41(3), 496-503. DOI: 10.1002/ceat.201700103

Gao, L., Deng, K., Zheng, J., Liu, B., and Zhang, Z. (2015). "Efficient oxidation of biomass derived 5-hydroxymethylfurfural into 2, 5-furandicarboxylic acid catalyzed by Merrifield resin supported cobalt porphyrin," Chemical Engineering Journal 270, 
444-449. DOI: 10.1016/j.cej.2015.02.068

Ghose, T. K. (1987). "Measurement of cellulase activities," Pure and Applied Chemistry 59, 257-268. DOI: 10.1351/pac198759020257

Gu, F., Wang, W., Jing, L., and Jin, Y. (2013). "Effects of green liquor pretreatment on the chemical composition and enzymatic digestibility of rice straw," Bioresource Technology 149, 375-382. DOI: 10.1016/j.biortech.2013.09.064

Hassan, N., and Idris, A. (2016). "Simultaneous saccharification and fermentation of lactic acid from empty fruit bunch at high solids loading," BioResources 11(2), 37993812. DOI: 10.15376/biores.11.2.3799-3812

Hassan, N., Idris, A., El-Enshasy, H. A., and Malek, R. A. (2017). “Scaling-up of simultaneous saccharification and fermentation of lactic acid from microwave-alkalitreated empty fruit bunches," BioResources 12(4), 8001-8013. DOI: 10.15376/biores.12.4.8001-8013

Hazeena, S. H., Salini, C. N., Sindhu, R., Pandey, A., and Binod, P. (2019). "Simultaneous saccharification and fermentation of oil palm front for the production of 2, 3 butanediol," Bioresource Technology 278, 145-149. DOI: 10.1016/j.biortech.2019.01.04

Kang, K. E., Park, D. H., and Jeong, G. T. (2013). "Effects of inorganic salts on pretreatment of Miscanthus straw," Bioresource Technology 132, 160-165. DOI: 10.1016/j.biortech.2013.01.012

Lai, L. W., and Idris, A. (2013). "Disruption of oil palm trunks and fronds by microwavealkali pretreatment," BioResources 8(2), 2792-2804. DOI: 10.15376/biores.8.2.27922804.

Lai, L. W., and Idris, A. (2016). "Comparison of steam-alkali-chemical and microwave alkali pretreatment for enhancing the enzymatic saccharification of oil palm trunk," Renewable Energy 99, 738-746. DOI: 10.1016/j.renene.2016.07.059

Láinez, M., Ruiz, H. A., Castro-Luna, A. A., and Martínez-Hernández, S. (2018). "Release of simple sugars from lignocellulosic biomass of Agave salmiana leaves subject to sequential pretreatment and enzymatic saccharification," Biomass and Bioenergy 118, 133-140. DOI: 10.1016/j.biombioe.2018.08.012

Latip, N. A., Sofian, A. H., Ali, M. F., Ismail, S. N., and Idris, D. M. N. D. (2019). "Structural and morphological studies on alkaline pre-treatment of oil palm empty fruit bunch (OPEFB) fiber for composite production," Materials Today: Proceedings 17, 1105-1111. DOI: 10.1016/j.matpr.2019.06.529

Liu, L., Sun, J., Li, M., Wang, S., Pei, H., and Zhang, J. (2009). "Enhanced enzymatic hydrolysis and structural features of corn stover by $\mathrm{FeCl}_{3}$ pretreatment," Bioresource Technology 100(23), 5853-5858. DOI: 10.1016/j.biortech.2009.06.040

Medina, J. D. C., Woiciechowski, A., Zandona Filho, A., Nigam, P. S., Ramos, L. P., and Soccol, C. R. (2016). "Steam explosion pretreatment of oil palm empty fruit bunches (EFB) using autocatalytic hydrolysis: A biorefinery approach," Bioresource Technology 199, 173-180. DOI: 10.1016/j.biortech.2015.08.126

Moodley, P., and Kana, E. G. (2017). "Development of a steam or microwave-assisted sequential salt-alkali pretreatment for lignocellulosic waste: Effect on delignification and enzymatic hydrolysis," Energy Conversion and Management 148, 801-808. DOI: 10.1016/j.enconman.2017.06.056

Nomanbhay, S.M., Hussain, R., and Palanisamy, K. (2013). "Microwave-assisted alkaline pretreatment and microwave assisted enzymatic saccharification of oil palm empty fruit 
bunch fiber for enhanced fermentable sugar yield," Journal of Sustainable Bioenergy Systems 30, 7-17. DOI: 10.4236/jsbs.2013.31002.

Palamae, S., Dechatiwongse, P., Choorit, W., Chisti, Y., and Prasertsan, P. (2017). "Cellulose and hemicellulose recovery from oil palm empty fruit bunch (EFB) fibers and production of sugars from the fibers," Carbohydrate Polymers 155, 491-497. DOI: $10.1016 /$ j.carbpol.2016.09.004

Qing, Q., Zhou, L., Huang, M., Guo, Q., He, Y., Wang, L., and Zhang, Y. (2016). "Improving enzymatic saccharification of bamboo shoot shell by alkalic salt pretreatment with $\mathrm{H}_{2} \mathrm{O}_{2}$," Bioresource Technology 201, 230-236. DOI: 10.1016/j.biortech.2015.11.059

Sai, Y. W., and Lee, K. M. (2019). "Enhanced cellulase accessibility using acid-based deep eutectic solvent in pretreatment of empty fruit bunches," Cellulose 26(18), 9517-9528. DOI: 10.1007/s10570-019-02770-w

Segal, L., Creely, J. J., Martin, A. E., and Conrad, C. M. (1959). “An empirical method for estimating the degree of crystallinity of native cellulose using the X-ray diffractometer," Textile Research Journal 29, 786-794. DOI: $10.1177 / 004051755902901003$

Sewsynker-Sukai, Y., and Kana, E. G. (2017). "Optimization of a novel sequential alkalic and metal salt pretreatment for enhanced delignification and enzymatic saccharification of corn cobs," Bioresource Technology 243, 785-792. DOI: 10.1016/j.biortech.2017.06.175

Sewsynker-Sukai, Y., and Kana, E. G. (2018). "Microwave-assisted alkalic salt pretreatment of corn cob wastes: Process optimization for improved sugar recovery," Industrial Crops and Products 125, 284-292. DOI: 10.1016/j.indcrop.2018.08.086

Sewsynker-Sukai, Y., Suinyuy, T. N., and Kana, E. G. (2018). "Development of a sequential alkalic salt and dilute acid pretreatment for enhanced sugar recovery from corncobs," Energy Conversion and Management 160, 22-30. DOI: 10.1016/j.enconman.2018.01.024

Shamsudin, S., Shah, U. K. M., Zainudin, H., Abd-Aziz, S., Kamal, S. M. M., Shirai, Y., and Hassan, M. A. (2012). "Effect of steam pretreatment on oil palm empty fruit bunch for the production of sugars," Biomass and Bioenergy 36, 280-288. DOI: 10.1016/j.biombioe.2011.10.040

Sluiter, A., Hames, B., Ruiz, R., Scarlata, C., Sluiter, J., Templeton, D. (2006). "Determination of structural carbohydrates and lignin in biomass," Golden, CO: National Renewable Energy Laboratory Analytical Procedure

Smits, J., van Haastert, M., Janse, A., Maas, J., de Graaf, K., Kroon, H., and Happel, A. (2019). "Scale-up of optimal mild-acid pretreatment conditions in the production and application of lignocellulosic sugars from wood," Bioresource Technology Reports 100361. DOI: $10.1016 /$ j.biteb.2019.100361

Sorn, V., Chang, K. L., Phitsuwan, P., Ratanakhanokchai, K., and Dong, C. D. (2019). "Effect of microwave-assisted ionic liquid/acidic ionic liquid pretreatment on the morphology, structure, and enhanced delignification of rice straw," Bioresource Technology 293, 121929. DOI: 10.1016/j.biortech.2019.121929

Sudiyani, Y., Styarini, D., Triwahyuni, E., Sembiring, K. C., Aristiawan, Y., Abimanyu, H., and Han, M. H. (2013). "Utilization of biomass waste empty fruit bunch fiber of 
palm oil for bioethanol production using pilot-scale unit," Energy Procedia, 32, 3138. DOI: 10.1016/j.egypro.2013.05.005

Sun, J. X., Sun, X. F., Sun, R. C., Paul, F., and Mark, S. B. (2003). "Inhomogeneities in the chemical structure of sugarcane bagasse lignin," J. Agric. Food. Chem., 51, 67196725. DOI: $10.1021 / \mathrm{jf034633j}$

TAPPI test method T203 cm-09. (2009). "Alpha-, beta- and gamma-cellulose in pulp," TAPPI Press, Atlanta.

Teramoto, Y., Lee, S. H., and Endo, T. (2009). "Cost reduction and feedstock diversity for sulfuric acid-free ethanol cooking of lignocellulosic biomass as a pretreatment to enzymatic saccharification," Bioresource Technology 100(20), 4783-4789. DOI: 10.1016/j.biortech.2009.04.054

Thamsee, T., Choojit, S., Cheirsilp, B., Yamseangsung, R., Ruengpeerakul, T., and Sangwichien, C. (2019). "Combination of superheated steam explosion and alkaline autoclaving pretreatment for improvement of enzymatic digestibility of the oil palm tree residues as alternative sugar sources," Waste and Biomass Valorization 10(10),

Van Soest, P. J., Robertson, J. B., and Lewis, A. (1991). "Methods for dietary fiber, neutral detergent fiber, and nonstarch polysaccharides in relation to animal nutrition," J. Dairy Sci. 74, 3583-3597, 3009-3023. DOI: 10.1007/s12649-018-0292-z

Wei, W., Zhang, H., and Jin, Y. (2019). "Comparison of microwave-assisted zinc chloride hydrate and alkali pretreatments for enhancing eucalyptus enzymatic saccharification," Energy Conversion and Management 186, 42-50. DOI: 10.1016/j.enconman.2019.02.054

Zhou, X., Wang, M., Fang, S., Liu, X., and Liu, P. (2019). "Effect of alkaline black liquor recycling on alkali combined with ozone pretreatment of corn stalk," Molecules 24(15), 2836. DOI: 10.3390/molecules24152836

Zulkiple, N., Maskat, M. Y., and Hassan, O. (2016). "Pretreatment of oil palm empty fruit fiber (OPEFB) with aquaeous ammonia for high production of sugar," Procedia Chemistry 18, 155-161. DOI: 10.1016/j.proche.2016.01.024

Article submitted: February 18, 2020; Peer review completed: April 18, 2020; Revised version received: May 4, 2020; Accepted: May 5, 2020; Published: May 11, 2020.

DOI: 10.15376/biores.15.3.4912-4931 